\title{
A LINHA DA DOBRA. ENSAIO DE COSMOLOGIA MESOAMERICANA*
}

Pedro Pitarch

\section{Introdução}

Suponhamos que uma cosmologia indígena pudesse ser resumida em uma figura ou, melhor, em uma operação. No mundo mesoamericano a dita operação seria a dobra. Uma dobra é a parte dobrada de uma matéria flexível - tecido ou papel - que permite que um dos lados se sobreponha ao outro de forma que o interior se situe no exterior e vice-versa. Tentarei mostrar como esta dobra distingue e articula os dois domínios nos quais se divide o universo indígena: o estado solar, extensivo e discreto habitado pelos humanos e demais seres ordinários, e o estado intensivo e virtual no qual habitam os espíritos. A polaridade humano/espírito constitui, de fato, a principal divisória entre os seres. Se na Amazônia a distinção humano/ não-humano parece corresponder principalmente à oposição humano/ animal (cf. por exemplo Viveiros de Castro 2002a:357; Vilaça 2005:451), em Mesoamérica o não humano é por antonomásia um espírito: deuses, almas, mortos, nahuales, fantasmas...

Estes seres do domínio intensivo se dobram sobre si mesmos para adentrar no mundo solar, assim como, inversamente, nós, os seres solares nos desdobramos - transitória ou definitivamente - para nos dissolvermos no domínio intensivo. Os dois estados - como em um tecido - formam o anverso e o reverso do cosmos. A dobra de um é o desdobramento do outro (como veremos, a finalidade provisória da dobra é formar um envoltório que constitui tanto um objeto como um conceito mesoamericano essencial). A menção aqui ao tecido não é, entretanto, casual, uma vez que o cosmos mesoamericano parece ser frequentemente pensado como uma peça indígena tecida. Uma peça reversível cuja operação de dobra permite a transição entre ambos os lados do tecido (cosmos). A alternância entre o anverso e o reverso é a diferença entre um estado descontínuo e um estado contínuo: se no primeiro o trançado das figuras é nítido e discreto, no segundo os motivos se desvanecem até perderem seus contornos. 
O que pretendo discutir aqui, então, não são os domínios da existência considerados em si mesmos, mas o modo em que eles entram em relação; o modo em que se articulam e traficam entre si por meio dessa linha de curva que os distingue e relaciona ao mesmo tempo. É claro que, neste caso, não faço senão seguir a proposição de Roy Wagner (1981), segundo a qual, em numerosas culturas (ainda que não na "nossa"), o foco de atenção não recai no que se relaciona, mas na relação em si: o importante não é o distinguido, mas a distinção mesma. Nas culturas mesoamericanas tal "distinção" - esse instante de atenção extrema - adota a figura da dobra; é isto que torna este movimento um conceito indígena elementar.

A intuição da dobra enquanto conceito indígena de relação advém do meu trabalho de tese doutoral (Pitarch 1996:251-252) sobre a relação corpo/ alma para os tzeltales, que ao todo são 400 mil indígenas localizados no estado de Chiapas, no sul do México. No entanto, aqui procuro - um tanto arriscadamente - expandir o conceito à área mesoamericana em seu conjunto. Trata-se de uma extensão geográfica considerável - grosso modo o território de México e Guatemala - e um vasto período de tempo - aproximadamente os 3 mil anos que perpassam a aparição das civilizações pré-colombianas (ou melhor, a aparição da arte têxtil) e o presente indígena. Com limites tão amplos, o melhor é começar pelos meus dados etnográficos tzeltales de Altos de Chiapas.

\section{A dobra do nascimento}

A língua tzeltal distingue dois estados do cosmos: jamalal, cujo significado literal é "mundo ou estado solar", é o mundo ordinário que habitam os seres humanos; e chalamal, que pode ser traduzido como "lado-duplo", "lado oposto" ou simplesmente como "outro lado", é o domínio dos espíritos. Tudo o que existe se divide entre estes dois domínios, mas a distância que separa um do outro não é de natureza física ou geográfica, senão ontológica.

O outro lado se caracteriza fundamentalmente pela sua multiplicidade e sua instabilidade ou variabilidade, o que Eduardo Viveiros de Castro chama de "multiplicidade virtual intensiva" ou "multiplicidade qualitativa" (2006:321-323). É um domínio que não pode ser cartografado, um estado instável que ignora as coordenadas cronométricas. Conforme os cantos xamânicos, o modo de orientação no outro lado - seu balizamento, por assim dizer - depende antes de dados sensíveis, tais como movimentos, cores, sons, temperatura, luminosidade... Trata-se de campos semióticos sem distinções constantes onde as divisões não são nítidas ou transparentes, já que se 
encontram em uma situação de indeterminação, ou seja, em um estado que não é nem de mistura nem de separação. Tal instabilidade dos espíritos é, em todo caso, o que impede reduzir o conjunto destes a uma ordem taxonômica. Os espíritos parecem se comprazer em desafiar qualquer tentativa de identificação e de ordenamento sistemático dos antropólogos. Fazem-no de forma semelhante ao modo como se divertem extraviando os indígenas na mata ou enganando-os com suas mudanças de aspecto em aparições: na hora em que parece que se vai alcançá-los, isto é, identificá-los, eles se transformam em outra coisa, e em outra, e em outra. Estes seres se transformam com grande facilidade, são grandes trapaceiros.

Do outro lado, o mundo extensivo é o resultado da aparição do sol, o acontecimento decisivo das mitologias mesoamericanas. A emergência do astro representa o "cronotopo" por antonomásia, no qual a luz e o movimento cronométrico dos astros originam as coordenadas estáveis de tempo e espaço (Gossen 1974). Os seres e os objetos solares formados por matéria sólida e opaca, que produzem sombra, possuem, independentemente das circunstâncias, uma identidade individual e relativamente estável. Porém, inclusive agora que o sol permite a vida tal e qual a conhecemos - ainda que seja de maneira provisória - o outro lado envolve esta dimensão solar e encontra-se permanentemente presente como o reverso da existência. É um "outro lado" sem fronteiras precisas. Durante o dia cede e se contrai como resultado da dilatação da luz solar e permanece nas sombras, essa outra maneira de chamar as almas ou, o que é o mesmo, a névoa espessa onde os intervalos desvanecem. Durante a noite se expande, invadindo o mundo solar, apenas respeitando o fogo dos lares que estão permanentemente acesos - ainda que seja com brasas cobertas de cinza.

É provável que o melhor modelo de relação (de dobra) entre estes dois estados da existência seja o processo do nascimento individual. O outro lado - e este é um dado crucial - não somente se situa "fora", mas também dentro de cada ser humano sob a forma do que convencionalmente chamamos de "almas". As almas são fundamentalmente fragmentos do outro lado encapsulados no interior do corpo - entre os Tzeltal, no coração - como resultado do processo do nascimento individual. Durante o período de gestação, o feto se encontra ainda numa situação transitória entre ambos os domínios, e se alimenta - como os espíritos - do sangue materno. Porém, o futuro corpo está dobrado, virado do avesso: seu interior ainda se encontra no exterior e vice-versa, de forma que as almas se situam fora do corpo, em contato com a placenta que o envolve. Durante o parto, o feto se dobra sobre si mesmo, aprisionado em seu interior e arrastando consigo, em direção ao mundo solar, as almas, as quais formarão parte da pessoa ao longo de sua vida indi- 
vidual $^{1}$. Com o falecimento do corpo - momento do desdobramento - esses fragmentos serão restituídos à sua dimensão original.

Um indício relativamente confiável para descobrir os tipos de almas do recém-nascido - ao qual, no entanto, recorre-se pouco na prática - consiste em examinar a superfície da placenta. As almas tzeltales (Pitarch 1996, 2010), como acontece em Mesoamérica de modo geral, constituem um numeroso e heterogêneo conjunto de seres: uma delas possui forma idêntica à do corpo humano que a acolhe, mas outras ("nahuales") são capazes de adotar a forma corporal de animais de qualquer espécie, ou então fenômenos atmosféricos, como raios, ventos, o arco-íris, e ainda figuras de aspecto europeu, como sacerdotes católicos, funcionários do rei da Espanha ou professores de escola ${ }^{2}$. O que se procura na placenta são, precisamente, pegadas que as almas tenham deixado impressas durante o período intrauterino: a pata do felino, a marca em ziguezague do raio, os sapatos do bispo. Dado que as almas e suas pegadas se excluem mutuamente por definição (cf. Ingold 1991:120), a placenta haverá de ser enterrada ou incinerada para que as almas possam permanecer no interior do corpo.

Este dobrar-se - a vida - representa, no entanto, uma conquista precária, sempre sob a ameaça de se desfazer. As almas podem abandonar o corpo e não voltar e, de fato, todo o problema reside na sua tendência a desdobrar-se em sua dimensão primordial. No fundo, a vida individual é uma luta orientada a segurar esses fragmentos no coração, menos um órgão do que um coágulo do estado pré-solar alojado no lugar mais interno do corpo. Entretanto, isto não evita que em situações como o sonho, a doença ou a embriaguez tenham lugar episódios inconclusos de desdobramento. Todas essas situações obrigam a experimentar em primeira pessoa o outro lado, incessantemente lembrando que esta forma de existência se encontra dentro de todos e em cada um de nós. Por fim, a morte dispersa os fragmentos que permaneceram unidos durante o período de vida no corpo (um envoltório) e a identidade pessoal se desintegra.

\section{Anverso e reverso}

Vale a pena deter-se brevemente em como se nomeia a dobra do nascimento na língua tzeltal: sbot' sba. A expressão designa um tecido ou uma vestimenta virado/a do avesso ou, para ser ainda mais preciso, a ação de virá-lo ao contrário. Nascer é assim pensado como a ação de inverter ou dobrar um tecido: passar do reverso ao anverso. A partir de uma revisão dos dicionários de línguas maias é possível deduzir que o verbo bot' (sba é 
o reflexivo) possui pelo menos duas grandes acepções, só aparentemente distintas entre si. Em primeiro lugar, significa dobrar algo ou, como vimos, virar do avesso um tecido e, igualmente, envolver e envoltório. Em segundo lugar, o verbo significa olhar algo fixamente, com intensidade, com os olhos totalmente abertos. Adiante voltaremos a esta enigmática segunda acepção; por enquanto prestemos atenção ao papel desempenhado pelo modelo do tecido como contato e transição entre os dois domínios da existência.

Em Mesoamérica, a relação com o outro lado é frequentemente expressa por meio de analogias têxteis, tais como tecer/destecer, dobrar/desdobrar, embrulhar/desembrulhar, atar/desatar, cobrir/descobrir, vestir/desvestir. Operações sob o tecido e a roupa representam a fórmula principal para provocar mudanças qualitativas de espaço e tempo, assim como alterações do ser. O enunciado "dobrar fibras vegetais" designa o ato de "implantar", "inventar", "transformar" e, como veremos, denota também uma mudança de ciclo temporal. Em um mito mixe de Oaxaca comentado por Perig Pitrou (2017:9), o demiurgo Täätyunpï, "aquele cuja atividade é ter ideias", produz vida sob a terra dobrando fibras para tecer. Não deve nos surpreender, então, que nas culturas mesoamericanas os têxteis representem - junto com a linguagem - a matéria artística privilegiada e, consequentemente, possuidora da maior eficácia ritual, isto é, alteradora. O tecido é o lugar da transformação.

Durante milênios - parafraseando Carlo Ginzburg - os mesoamericanos foram tecelões. O desenvolvimento e a extensão do tecido há pelo menos 3 mil anos (cf. I. Weitlaner 1967) deve ter produzido uma espécie de revolução psicológica na conceptualização do $\operatorname{cosmos}^{3}$. Encontramos um eco desse processo entre os Pueblo: Spider Woman, um dos principais personagens mitológicos, ensina os humanos a cultivar e tecer algodão, de forma que não precisem se cobrir com peles, e constrói o primeiro tear de cintura: os polos cruzados foram feitos de fibras do céu e da terra; as varas, da urdidura dos raios solares; o carretel de linha, do relâmpago e da chuva; a fita, do halo solar; o pente, de conchas brancas, e assim por diante. Um tear cósmico. Cada vez que Spider Woman contorna o seu tear provoca uma mudança no mundo, precipita uma nova era (G. Reichard 1972).

Cecilia Klein (1982) observou que as representações pré-colombianas mesoamericanas mostram um universo circundado e contido por tecidos ou tramas compostos por fios e fibras de diferentes tipos. As imagens das "entradas cósmicas" do céu e do inframundo são, com frequência, indicadas pelo signo da esteira vegetal, e o universo é mostrado como uma pilha de tecidos que, ao depositar-se, vai se dobrando em camadas via a mudança de sentido (Klein:24-25). Johannes Neurath (2013:79-81) explica que na mitologia huichol o mundo é descrito como um tecido elaborado com o 
cabelo da deusa primordial, enquanto os teares de cintura representam uma paisagem ritual na qual os fios são os caminhos de peregrinação, ou seja, de transformação. Por fim, motivos como a mudança de vestimenta, a destruição de velhos tecidos ou a estreia de peças novas são onipresentes nas narrativas e na ação ritual mesoamericana.

Uma das consequências deste modelo têxtil é transformar o cosmos numa estrutura reversível. Entre ambos os lados da existência não há distância ou espessura, somente o anverso e o reverso de uma tela. Por isso que passar para o outro lado é tão fácil - e perigoso - porque o outro lado está aqui entre nós, todas as coisas do nosso mundo solar possuem um outro lado. A etnografia proporciona uma infinidade de exemplos destas transições nas quais os humanos se encontram repentina e imperceptivelmente do lado do mundo dos espíritos. É suficiente inverter a tela para situar-se no domínio intensivo do ser. Assim como acontece com uma luva que é virada do avesso, o exterior se situa no interior e vice-versa, sem que - e isto é fundamental - a peça deixe de ser a mesma. O tecido contém ambas as perspectivas e a dobra as transpõem em um jogo de reversão sem fim no qual ambos os lados se requerem mutuamente. Em um universo facultativamente reversível onde é tão fácil deslizar de um ao outro lado e, portanto, perder o sentido da posição, o próprio tecido funciona como ponto de referência ${ }^{4}$.

Suspeito que boa parte do que, nas descrições etnográficas, é chamado de transformação sobrenatural ou metamorfose pessoal (um ser humano se transforma em...) pode ser interpretado por meio da figura da dobra. Na língua náhuatl do centro do México, por exemplo, o termo cuepa, que em sua forma reflexiva designa o ato de "transformar-se" em um nahual (a alma-animal pessoal), significa literalmente "virar algo do avesso", as vestimentas, por exemplo (Chamoux 1989:306). Vestir-se com as roupas do lado do avesso ou enrolar um bebê no sentido incorreto - explicam as mães no Altos de Chiapas - é situar-se no mundo dos mortos. Meus amigos tzeltales me aconselharam em diversas ocasiões que se caminhasse à noite e encontrasse um espírito, o que deveria fazer era virar rapidamente a minha roupa do avesso de forma que o reverso ficasse como anverso. Dessa forma, o espírito não pode atacar. A eficácia da operação reside verossimilmente na relação tanto de semelhança como de contiguidade entre a roupa e a pele. A pessoa "vira do avesso" e mostra o lado interior de si mesmo, isto é, o outro de si mesmo. Desdobrando-se, o humano deixa de sê-lo e se situa em um estado análogo ao do espírito que o ataca que, ipso facto, perde qualquer poder sobre sua vítima. Segundo me explicou um indígena, em uma situação assim, "o espírito sente vergonha de si mesmo". Por tomar súbita consciência do inapropriado de sua ação ao se tratar a vítima de 
um semelhante? Por ser incapaz de apreender a si mesmo através de um humano que deixou de sê-lo?

Então, não parece que exista em sentido estrito uma mudança de forma - no modo em que está distribuída a matéria em um corpo - mas uma "troca de lado". Os nahuas de Sierra de Puebla chamam esta mudança de kixpatla, traduzido significativamente por Alessandro Questa (2018) como "troca de rosto, troca de visão". Kixpatla designa a capacidade xamânica de passar ao mundo invisível, ou seja, de transitar entre ambos os lados do cosmos. Resulta revelador que os nahuas descrevessem a Questa tal transição ora como a sucessão de peles de uma cebola, ora como o embrulhamento progressivo de um objeto por uma tela, isto é, como uma superposição ou uma dobra. De fato, nas línguas mesoamericanas, as ações de dobra e superposição - não necessariamente horizontal - parecem ser equivalentes para todos os efeitos. Citando um exemplo, o vocabulário de língua cakchiquel de Fray Tomás de Coto (1983) traduz o termo tin tun, cujo significado literal é "colocar uma coisa sobre outra", como "dobrar". Mas este é também o sentido literal do verbo "dobrar" em espanhol: dobrar uma coisa mole de forma que uma parte dela seja aplicada sobre a outra, uma ou mais vezes (Moliner 1975).

Além disso, tal equivalência entre superposição e dobra permite, com efeito, conciliar duas interpretações do cosmos indígena aparentemente antagônicas. A primeira responde ao modelo convencional de um cosmos composto por níveis superpostos; a segunda a um cosmos formado por dois lados ontologicamente distintos (Pitarch 2010). Minha impressão é a de que o modelo de níveis superpostos é, ao mesmo tempo, correto e ilusório. Correto porque as referências na etnografia indígena à presença de "níveis" são irrefutáveis (por mais que raramente tenhamos conhecimento do termo indígena que os designa). Mas também ilusório porque é improvável que esses níveis formem, na conceituação indígena, um espaço geográfico unificado. Não há propriamente espaço, isto é, um contínuo homogêneo, mas lugares. Longe de ser algo dado a priori, um "lugar" adquire existência em função dos objetos e seres que envolve. E visto que os seres do outro lado se encontram em permanente transformação, também os lugares que ocupam se transformam com eles. Isto me leva a imaginar que os "níveis" não se encontram localizados em um mesmo plano geométrico (da forma em que estão, por exemplo, os "círculos" da Divina Comédia), mas que ocupam campos topológicos diferenciados. A correspondência entre superposição e dobra sugere que se entendermos "nível" como um tecido dobrado sucessivas vezes, a transposição de nível é na realidade uma mudança de lado, isto é, de estado. 


\section{As dobraduras do corpo}

Podemos lembrar também que tecido e pele funcionam em Mesoamérica como princípios equivalentes, de forma que a pele possui igualmente a faculdade de induzir uma "mudança de lado". Não é necessário insistir no motivo ritual pré-colombino do esfolamento e a dança mexicana do tlacaxipehualiztli ("esfolamento ou troca dos homens") na qual os executantes se vestiam com a pele humana completa, rosto inclusive, de cativos recém-esfolados. O que chama a atenção, precisamente, é que a pele era invertida de tal forma que o lado interno - o lado sangrante - ficava como o lado visível durante o espetáculo. Inga Clendinnen (1991:233) nos fornece uma pista quando observa que o deus Xipe Totec - o Senhor Esfolado - não seria representado pelo corpo dos dançarinos, mas sim, justamente, pela pele sangrante que cobria seus corpos.

No entanto, onde se evidencia com maior nitidez a relação entre a pele e a transição é na etnografia de Jacques Galinier sobre os Otomi da Sierra Madre Oriental, em que "o passo em direção ao sagrado se expressa por referência aos semas 'pele' e 'podridão'" (1990:620). Vestir-se durante a festa de carnaval - o que chamamos equívocamente "fantasiar-se" - consiste em verdade em numa troca de pele, o que equivale a dizer, em uma troca de lado. (Não é casual, como veremos, que em otomí o termo para carnaval signifique também "espelho"). Esta capacidade dérmica de mudar de lado se revela, por exemplo, no simbolismo das célebres figurinhas recortadas em papel da árvore amate, cuja "pele vegetal" equivale à pele humana.

Em todas as comunidades da Sierra Madre, o ato de esfolar a casca do amate é uma metáfora da "pele" arrancada, isto é, da mudança de identidade, a qual permite passar a tâkwati "do outro lado". Também serve para marcar a oposição entre o visível e o invisível, o mundo "diurno" e o mundo "noturno", o que se consegue precisamente via o "esfolamento" ou "desvelamento". Assim procede o xamã que "esculpe" no vivente esta pele vegetal sobre a qual vai se recortar uma entidade que pertence ao "mundo do outro lado" (Galinier 2000:03).

Na realidade, o universo otomí parece pensado como formado por peles: peles que se superpõem, peles que se dobram, peles que formam envoltórios, peles que, por assim dizer, produzem lugares. Um universo de contornos epidérmicos onde, de novo, superposição, dobra e envoltório são aspectos de uma mesma operação. Os antecessores, explica Galinier, se encontram envolvidos em pele, a qual deve ser aberta para que a vida possa se regenerar. A superposição destes receptáculos dérmicos tem seu paralelo na delimitação simbólica dos espaços rituais, os quais são definidos como 
envolturas: "A noção de envoltura é essencial: assim no céu, mahes'i, 'o lugar da pele venerável', é percebido como uma espécie de roupagem do mundo, da gruta, do oratório, da casa como projeção da cavidade uterina" (Galinier 1990:131). "Roupagem do mundo": permanecemos nas metáforas têxteis.

Por outro lado, convém prestar atenção ao modo como as próprias dobras do corpo humano funcionam como um meio de comunicação com o outro lado. Desde o norte do México até a Centroamérica (cf. Tedlock 1982), os xamãs diagnosticam as doenças, e em alguns casos prognosticam o futuro, auscultando a dobra das articulações: o interior dos punhos, dos cotovelos, dos joelhos ou de qualquer outro ponto em que o corpo humano se dobra. $\mathrm{O}$ que procuram os especialistas quando apalpam com as pontas dos dedos o movimento do sangue não é tanto medir o ritmo sanguíneo mas sim escutar a linguagem que transporta. "O sangue fala", se diz por toda a área mesoamericana, devendo se tomar a expressão de modo totalmente literal. Os espíritos pronunciam certos discursos patógenos - frequentemente escritos e enviados "embrulhados" - os quais se introduzem no corpo da vítima pelo interior das dobras das articulações, de onde passam ao fluxo sanguíneo e se distribuem pelo corpo (Pitarch 2013).

O que pode significar que a doença se introduza precisamente pelas dobras e não, por exemplo, pelos orifícios corporais? Peter Mason (1990) argumenta que as articulações corporais constituem um sistema conectado com a articulação da linguagem. Os orifícios corporais representam um sistema de pontuação. A pontuação produz intervalos, introduz divisões entre entidades e domínios; como a pontuação do texto, a pontuação do corpo (seus orifícios) cria separações, define seus limites. No entanto, as dobras se apresentam como um código de articulação, e as articulações relacionam. As dobras do corpo operam a relação entre este e o outro lado por meio de uma articulação simultaneamente somática e linguística. Possibilitam tanto a introdução da doença desde o mundo dos espíritos como a audição/tato dessa linguagem por parte dos xamãs. Por eles, sabemos que a linguagem do outro lado é basal, e nela se confundem idiomas como o espanhol, o inglês, o latim e algumas línguas indígenas, junto com barulhos, balbucios alcoólicos e expressões sentimentais.

\section{Envoltórios}

A natureza reversível do cosmos mesoamericano implica que se um ser humano se desdobra para passar ao outro lado, os fragmentos do outro lado devem, do mesmo jeito, dobrar-se para adentrar no domínio solar. É preciso 
destacar que para poder permanecer de modo prolongado no mundo do sol, estes fragmentos não devem simplesmente dobrar-se sobre si mesmos, mas devem manter-se embrulhados em tecidos, formando um "envoltório". A mesma inflexão da dobra produz a inclusão:

Por que alguma coisa seria dobrada - se pergunta Gilles Deleuze (1991:43-44) a propósito da dobra barroca - se não fosse para ser envolvida, para ser posta em outra coisa? [...] Trata-se de um envoltório de inerência ou de "inesão" unilateral: a inclusão, a inerência, é a causa final da dobra, de modo que se passa insensivelmente desta àquela. Produz-se entre as duas um deslocamento que faz do envoltório a razão da dobra: o que está dobrado é o incluído, o inerente. Dir-se-á que o que está dobrado é somente virtual e que só existe atualmente em um envoltório, em algo que o envolve.

Por toda a região mesoamericana, onde são conhecidos como bultos ou atados (e também na América do Norte, entre os Pueblo e desde as planícies até os grandes lagos e a bacia do Mississipi [Desvaux 1988], onde são conhecidos como sacred bundles), estes envoltórios funcionam como sacra, objetos de poder em si mesmos.

\section{Figura. 1. Bulto huichol do deus Tatutsi Uisteuári.} Museu Etnológico de Berlim

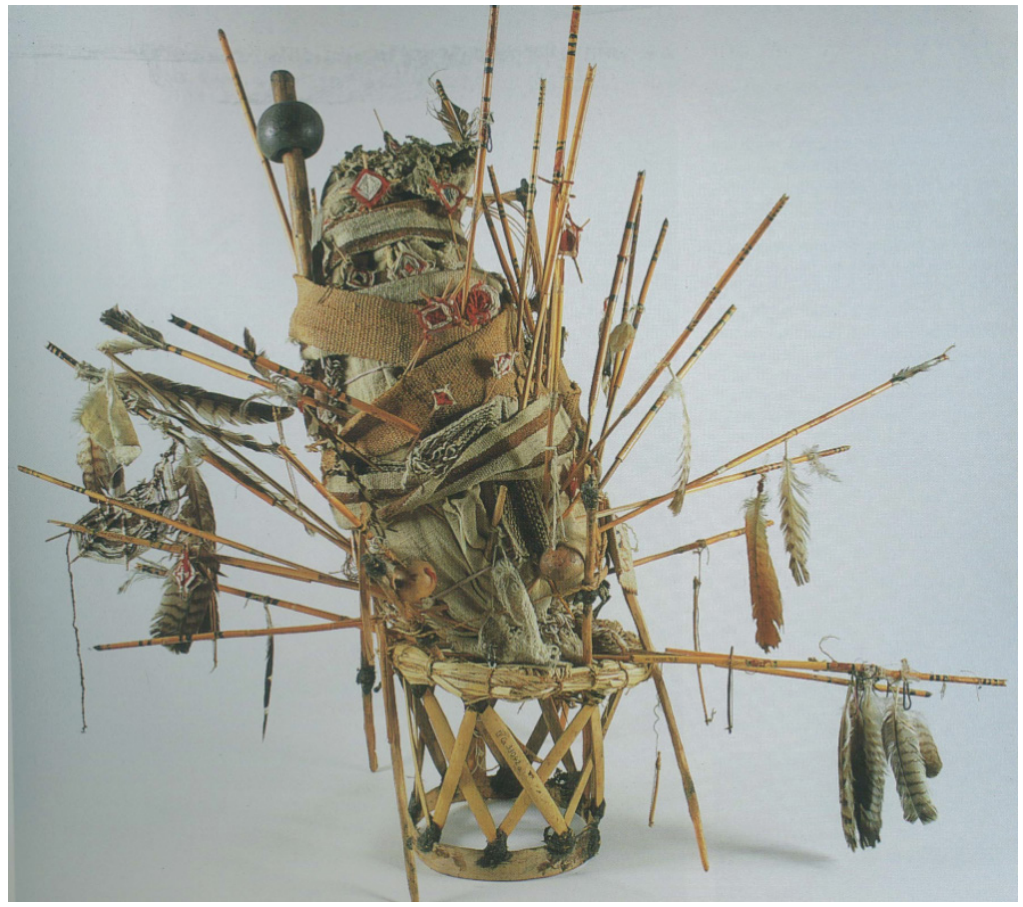


Entre os nahuas antigos se chamavam tlaquimilolli, "coisa enrolada assim", do verbo "embrulhar com um tecido" ou "amortalhar o morto", e o frei Andrés de Olmos chegou a afirmar que tais embrulhos eram "o principal ídolo que tinham em muita reverência" (Olivier 2007:281). Em alguns casos, os bultos continham a efígie de uma divindade, mas na maior parte deles o seu conteúdo eram pequenos e humildes objetos (Megged 2010); tanto que os inquisidores de idolatrias, decepcionados, os qualificaram de "miudezas" e "quinquilharias" (Castañeda 2016:57). O que de fato chama a atenção a partir de uma perspectiva europeia é a desproporção entre a ostentação da embalagem e a aparente modéstia de seu conteúdo. Por exemplo, o bulto do deus mexica Tezcatlipoca continha um espelho de obsidiana, pedras, um fêmur e uma tela de algodão com a pintura de alguns ossos humanos (Olivier 2007:290). Outro exemplo: o bulto que deixaram os primeiros governantes quichés da Guatemala a seus herdeiros guardava ossos de falange de águia, ossos de puma e de jaguar, cabeças e patas de veado, pedras negras e amarelas, grinalda metálica, penas de quetzal e de garça, rabo de abutre, flauta de osso, tambor e caracóis e uma bolsa para transportar tabaco (De la Garza 2012:160). A respeito deste último bulto, o livro de Popol Vuh (1947:140) observa um pouco enigmaticamente que "seu conteúdo era invisível porque estava embrulhado e não poderia ser desembrulhado; não se via a costura porque não se viu quando o embrulharam". Como se o fato de que a costura não fosse visível tornasse impossível abrir o embrulho, ou seja, reforça-se sua permanência no mundo solar.

O interior do embrulho, então, se caracteriza - como a galeria de almas alojada no coração humano ou os espelhos indígenas (ver adiante) - por sua multiplicidade e heterogeneidade. Mas, por diversos que sejam os objetos, chama a atenção a frequência com que aparecem fragmentos de corpos, humanos e animais. Trata-se, no entanto, daquelas partes que os tzeltales (Pitarch 2012) consideram como não compreendidas no "corpo carnal": nos humanos, cabelo, unhas e ossos; nos animais, bicos, presas, garras, cascos, penas, chifres, todas elas pensadas como enfeites do corpo carnal. Seu denominador comum é que por elas não circula o sangue, sendo o sangue um dos atributos definidores dos seres solares. Desta forma, são partes "espiritualizadas", pertencentes ao outro lado: aquelas que continuam crescendo depois da morte e que se apresentam como separáveis, suscetíveis de vaguear autonomamente ou de se colocar em outros corpos ${ }^{5}$. São precisamente estas partes que os humanos pegam para se adornar: dadas, podem ser tomadas (Viveiros de Castro 2002b:443). Isto significa que se os corpos são unidades discretas, estes fragmentos funcionam como "relatores" que unem ou associam corpos distintos. É precisamente por poderem se 
separar de um corpo que são capazes de unir vários corpos: "fragmentos contínuos", por assim dizer.

Contudo, aquilo que constitui o envoltório em um objeto transcendental - o principal ídolo indígena, em palavras de Frei Andrés de Olmos - não é o seu conteúdo, mas a própria operação de envolver: não tanto um continente, mas sim um operador. A dobra do outro lado só pode permanecer neste lado solar na medida em que ela mesma se torne um envoltório, que é, em definitivo, aquilo que garante a flexão. Por um lado, mediante a figura do envoltório, a multiplicidade de objetos se torna uma unidade ou, mais precisamente, a unidade envolve a multiplicidade ${ }^{6}$. Por outro lado, o interior forma um volume, no mesmo sentido em que se fala de uma figura de bulto, que é a qualidade daquilo que ocupa um espaço no mundo solar. Dito de outra forma, ao ser envolvido, o conteúdo adquire a extensão da qual o estado intensivo do outro lado carece. Em bons termos estruturalistas, o envoltório efetua a transição entre o contínuo e o discreto: um bulto é uma figura isolada, visível em todo o seu contorno, algo mensurável e que, portanto, introduz uma solução de continuidade no mundo pré-solar. É esta separação que permite capturar e fixar provisoriamente as capacidades e os afetos, de outro modo flutuantes, de um espírito, uma divindade ou qualquer outra agência sobrenatural. O envoltório dota de uma existência atual os fragmentos do domínio virtual que se introduziram neste mundo. Deleuze, já citado: “Dir-se-á que o que está dobrado é somente virtual e que só existe atualmente em um envoltório, em algo que o envolve" (1991:44).

Entre as populações indígenas contemporâneas é também fácil reconhecer esta imperiosa necessidade de manter o "sagrado" envolvido em tecidos ou esteiras vegetais (petates). Encontramo-nos aqui tanto com objetos da tradição pré-colombiana como com imagens católicas, e inclusive objetos preciosos, como os livros de ordenanças outorgadas pelo rei da Espanha ou as bíblias evangélicas. Na região de Altos de Chiapas, por exemplo, as imagens católicas são envolvidas em 13 vestidos, número que denota totalidade e encerramento, e a limpeza de suas roupas nos mananciais representa um evento ritual de máximo alcance e também risco para os mordomos cuidadores (cf. fig. 2). Por todo o México e a Guatemala as cruzes são "vestidas", como se não pudessem permanecer nuas neste lado solar da existência. Os adivinhos guardam seus cristais e contas - recebidos de maneira prodigiosa - firmemente envolvidos em panos. Cabe deduzir que, se não se mantiver envolvido, o conteúdo corre o risco de desaparecer, desdobrando-se, dispersando-se, e retornando assim ao seu estado original. 
Figura 2. Transporte de santo envolvido, Altos de Chiapas.

Foto José Ángel Rodríguez

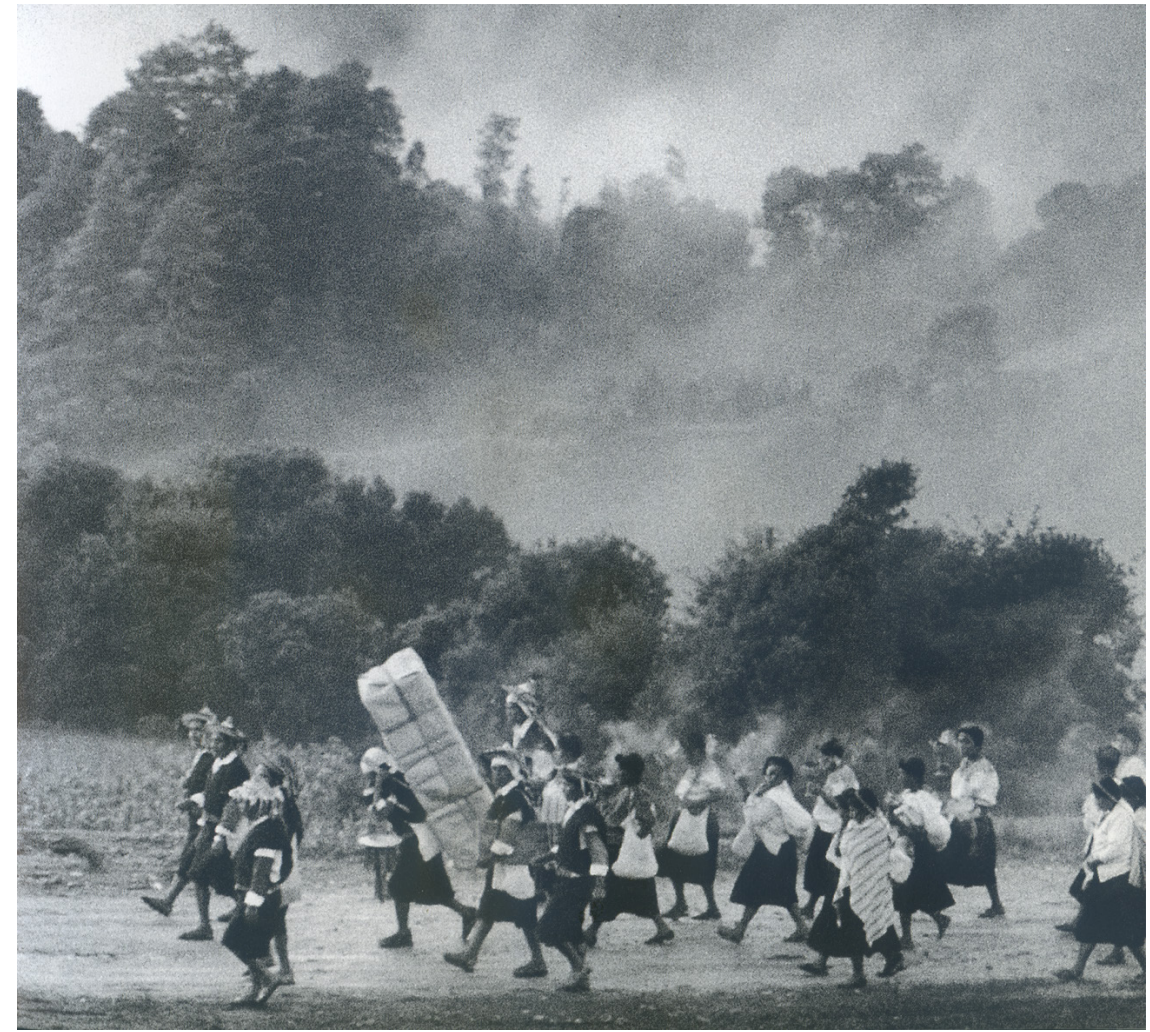

O conceito de envoltório se estende, de fato, a numerosos aspectos mesoamericanos aparentemente distantes do que se pode entender como um bulto atado. Citarei dois exemplos nas línguas maias. O primeiro é o termo pixan, traduzido correntemente por "alma", mas cujo significado literal é bulto ou envoltório, do verbo pix, cobrir, envolver. Assim, o que define a alma indígena - como vimos - não é tanto a essência, mas sim a sua condição de dobra: um coágulo do outro lado incluso no corpo. Contudo, pixan designa tanto aquilo que é envolvido como aquilo que envolve: um ente reversível em que o lado envolvido passa a envolver, e vice-versa.

O segundo exemplo é o nome do jaguar, balam, em que o sema bal significa "envoltório", "bulto", "mancha" (cf. Barrera Vásquez 1948:31). O jaguar, então, não é propriamente um animal, mas um embrulho do outro lado que perambula livremente pelo mundo solar. Mas o fato de bal significar também "mancha" sublinha a sinonímia entre a figura da dobra, o envoltório e a necrose dos tecidos vivos, como a pele. Vimos entre os Otomí a equivalência entre pele, putrefação e "passo ao sagrado". O que as manchas na 
pele do jaguar revelam é a contaminação da doença e da morte procedente do outro lado e que se manifesta por meio das cores vermelha e preta, as cores da escrita, aliás (Pitarch 2013).

\section{Nota sobre "a dobra do tempo"}

Gostaria de dar ainda mais um passo e sugerir uma relação geral entre o tecido, o conceito de dobra e a imaginação do tempo em Mesoamérica. Trata-se de uma relação complexa que exige uma discussão impossível de desenvolver aqui, mas sobre a qual se pode sugerir alguma observação preliminar. A convenção historiográfica nos instruiu a conceber o tempo mesoamericano como essencialmente cíclico ou, para ser mais preciso, circular. Um movimento circular cuja principal metáfora é, claro, a roda calendárica (estranha imagem para uma civilização que não emprega a roda). No entanto, numerosos indícios sugerem que uma metáfora mais adequada em termos indígenas seria a de um tecido ou uma tela susceptível de ser dobrada e desdobrada, embrulhada e desembrulhada, dobrada e endireitada. Na língua maia-yucateca, o verbo buk', que designa a "contagem dos anos", significa igualmente "tecer".

Um dos melhores exemplos se encontra nos livros de Chilam Balam, uma coleção de textos maias da península de Yucatán, de caráter histórico e profético, transcritos para o alfabeto latino pelos próprios indígenas durante o período colonial. Neles, os períodos de tempo - especialmente os ciclos de 7.200 dias ou 20 anos, $k^{\prime}$ atun - finalizam com a sua dobradura, dando lugar a um novo ciclo, ou seja, a um novo tempo. O momento da mudança de ciclo, então, não é outra coisa senão uma troca de lado da tela. No livro de Tizimín (Edmonson 1982:20), por exemplo:

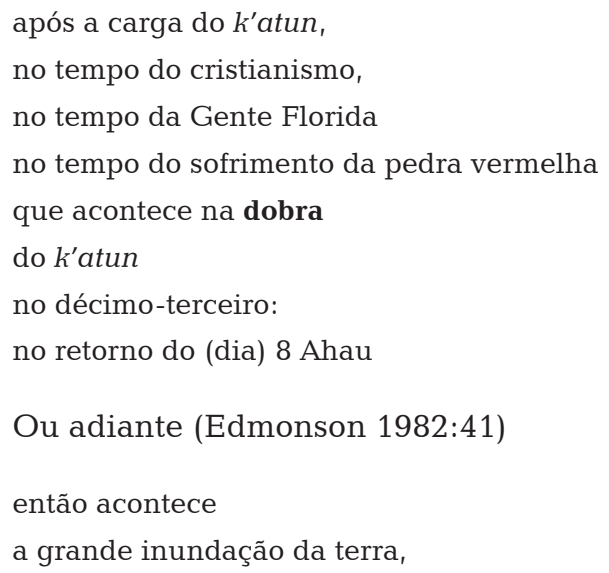


então emerge

o grande Itzam Cab Ain

a conclusão da palavra

a dobra do $k^{\prime}$ atun:

é uma grande inundação

será a conclusão da palavra do $k^{\prime} a t u n$

Que imagem é esta de um ciclo que se dobra como se fossem os relógios de Dalí? O termo traduzido por "dobra" nestes e em outros exemplos é utz', cujo significado é "dobrar", "amarrotar a roupa", mas também desviar-se de um caminho, por exemplo. Em outros casos, o fim do ciclo é designado com os seguintes verbos: uatz', que significa "interior de uma esquina" (os ângulos arredondados das casas maias-yucatecas), "curva", "velhice" (quiçá a dobra final do período de vida) e "dobrar os pés de milho" (para que não apodreça a espiga); ou $t z^{\prime} u$, que significa "amolecer, suavizar as coisas" (talvez, para que se produza uma dobra, a superfície deva ser macia, caso contrário, quebra); ou, finalmente, bal, que além de "envoltório" - como vimos no caso do jaguar - significa "juntar fibras ou fios para torcer" (Barrera et al. 1980). O que prevalece nestas imagens, então, não é o retângulo (esquinas) nem o círculo - as duas figuras com as quais convencionalmente se representou, respectivamente, o espaço e o tempo mesoamericano - mas a curvatura.

Dennis Tedlock (2010:250) observa que no Livro de Chumayel os marcos de uma série de acontecimentos históricos são separados por dobras (utz'), segundo o modelo da fabricação de um tapete vegetal (petate). O tapete retangular se elabora entrançando duas faixas vegetais, de forma que, uma vez concluído, cada um dos lados compridos do tapete representa quatro dobras e cada um dos lados curtos, duas, somando 12. A chegada de um novo acontecimento, o décimo terceiro, implica a confecção de um novo tapete de 12 dobras.

Mas como poderíamos quiçá esperar, o tempo não somente se dobra, mas também se embrulha. As estelas em pedra do período clássico maia eram erigidas a cada intervalo de 20 anos ( $k^{\prime}$ atun) e, ao concluir esse período, eram objeto de uma cerimônia em que eram embrulhadas com bandas de pano (Stuart 1996:155-158). O título da grande cerimônia mexicana do Fogo Novo, quando, por ocasião da conclusão de um período de 52 anos, todos os fogos eram apagados e somente voltavam a ser acesos no momento em que o sol aparecia novamente no horizonte, era xiuhmohpilli: o "envoltório dos anos", ou seja, o ato de envolver esse período de tempo.

Tudo isto parece sugerir que os ciclos (de 20 ou 52 anos) são pensados como um período no qual, por assim dizer, o tempo se encontra desdobrado, com a exceção do momento de conclusão do ciclo, quando o tempo deve ser 
envolvido. Isto coincide com uma surpreendente observação de Roy Wagner (2013:132) sobre a Cuenta Larga maia: "O tempo para os antigos maias não existia nos ciclos mesmos, mas nas INTERSEÇÕES dos ciclos" (ênfase de Wagner). E contínua: "Ao invés de imaginar os ciclos da Cuenta Larga como rodas ou círculos, se imaginavam como linhas retas que coincidem com uma esquina, ou dobra" (minha ênfase). Lembremos que o fim do ciclo é, de fato, a curva de uma esquina (uatz'). Em todo caso, esta é a dobra que vem a ser um envoltório provisional. Os intervalos temporais devem ser retidos mediante um envoltório no mundo solar naqueles momentos de transição cíclica, que coincidem com a desaparição provisória do sol, caso contrário o outro lado absorveria definitivamente este tempo solar cronométrico.

Existe, igualmente, uma estreita relação em Mesoamérica entre a mudança de vestimenta e o começo de um novo ciclo temporal. Isto é particularmente evidente nos mitos sobre a emergência do sol. No relato tzeltal, o astro não pode fazer a sua aparição - não pode iniciar a sua época - até obter 13 vestidos. As cores destes compreendem um gradiente do vermelho ao amarelo, e o sol os superpõe sucessivamente em seu percurso do amanhecer ao zênite, assim como vai se despojando deles do zênite ao crepúsculo, de forma que cada troca de vestido - cada capa têxtil - define os marcos horários diários. Para obter estes vestidos, tanto o sol como sua mãe, a lua, tiveram que se desfazer previamente de suas roupas velhas e tapetes, de modo análogo a como nos rituais do "fogo novo" os humanos devem queimar suas roupas velhas e estrear outras novas. No mais, este percurso solar reflete o princípio mesoamericano mais geral de subordinação temporal à extensão espacial: o agora é aqui e o antes é ali. Toda mudança temporal implica um deslocamento espacial ${ }^{7}$.

Uma comunidade que escolhe coletivamente mudar a indumentária induz uma transformação social e cósmica por meio da precipitação de um tempo novo. A conversão a alguma igreja cristã ou a decisão de "modernizar-se", por exemplo, exige uma mudança prévia de uniforme. Um ancião kanjobal de Chiapas resume este princípio quando explica que "antes de chegarem os missionários aqui não havia religião; a religião chegou quando a gente começou a usar sapatos" (Hernández Castillo 1989:145). Se bem entendido, o que afirma é que - literalmente - enquanto andavam descalços ou com sandálias não podia se produzir uma conversão religiosa, mesmo que assim o tivessem querido. Somente quando passaram a usar sapatos e mudar o estilo da roupa é que começou a se consumar a conversão. Ou, mais exatamente, o que se produziu foi uma dobra do tempo, uma súbita aceleração qualitativa do tempo induzida pela mudança de indumentária. Se nossa sociologia interpreta o tema clássico da "mudança coletiva de 
indumentária" como produto ou sintoma da mudança sociocultural, de uma perspectiva indígena, é justamente a mudança de roupa o que precipita a mudança de tempo, sua causa ou desencadeante.

\section{Imagens das origens no espelho}

Vimos acima que a expressão sbot' sba utilizada para designar a transição do nascimento admite uma dupla tradução: 1. "dobrar-se ou virar ao contrário"; 2. "olhar fixa, intensamente, a si mesmo, com os olhos bem abertos".

Dos dois, o significado menos evidente é provavelmente "olhar intensamente a si mesmo". Mas podemos captar ainda um pouco melhor o seu sentido se prestamos atenção ao que acontece quando os mesoamericanos se olham deste modo no espelho. Nos vasos do período clássico da civilização maia (300-900 a.D.) são frequentes certas cenas nas quais um dignitário é representado se olhando em um espelho. Tais cenas têm sido interpretadas apropriadamente como um tipo de ato de visão xamânica (De la Garza 2012:158-160; Reents-Budet \& Bishop 2012:324-325). O que chama a minha atenção, no entanto, é a fixidez do olhar e, principalmente, a abertura dos olhos do dignitário. No caso da Figura 3, isto se destaca ainda mais, tanto porque as pupilas parecem estar dilatadas como pelo contraste com o olhar "perdido" para cima e para baixo das duas personagens assistentes, uma das quais segura o espelho (possivelmente de pirita negra). O que sugiro, em definitivo, é que estas cenas representam a ação de sbot' sba: ao se olhar fixamente no espelho, a personagem está se dobrando - mais exatamente, se desdobrando - para passar ao outro lado. Um vocabulário de língua maia-kekchí traduz bot' por dobra, e acrescenta "por se olhar no espelho, dizem".

Figura 3. Vaso K4338. Archivo Justin Kerr

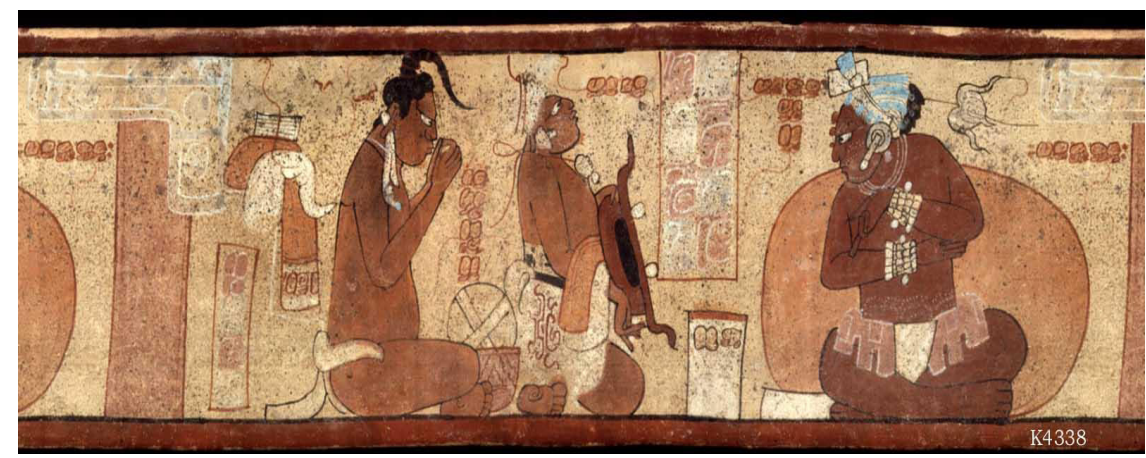


A prática de empregar espelhos como instrumentos de visão encontra-se relativamente difundida entre os indígenas mesoamericanos contemporâneos. O caso mais bem conhecido é o dos xamãs huichol da Sierra Madre Occidental: em sua imagem (nierikate) refletida no espelho o xamã huichol não vê a si mesmo, mas uma divindade ou "antepassado deificado" - ele mesmo transformado naquele - com quem mantém um diálogo durante as sessões de canto (Neurath 2008). Um segundo exemplo possivelmente mais revelador: os Huave, pescadores das lagunas do Istmo de Tehuantepec, afirmam que quando se coloca o rosto do recém-nascido diante de uma superfície de água do mar, o reflexo mostra os nahuales da criança. "Vê-se a cara de cada criança, mas o seu nahual. Vê-se que nahual é a criança, se é tartaruga, tubarão ou qualquer animal" (García Souza 2017:68). Aqui "nahual" designa tanto a alma-animal pessoal como uma humanidade mitológica que alterna traços humanos e animais. Enfim, que um espelho sirva de acesso ao outro lado não tem provavelmente nada de surpreendente, como mostra a história de Alice Através do Espelho. O distintivo no caso mesoamericano é que o faça através da própria imagem. O espelho, enfim, desembrulha, desdobra a pessoa. Olhar para si mesmo, intensamente, com os olhos abertos de par em par, é ver o passado mitológico do mundo.

A própria imagem, então, não é própria, é o aspecto mais estranho de si mesmo. Como conta Roy Wagner (2010:vi) o que lhe relatou um nativo de Nova Guiné: "Aquele a quem você vê quando olha na superfície da água ou de um espelho não é você e nem sequer é humano"8 (ênfase no original). Para seguir com a linguagem de Wagner, trata-se de uma inversão figura-fundo, uma troca entre sujeito e objeto, em que o último (ou os últimos) se apropria (m) dos olhos/rosto da pessoa e toma(m) o controle do seu olhar por meio da inversão deste sobre si mesmo ${ }^{9}$.

Na verdade, ainda carecemos de uma teoria compreensiva da imagem mesoamericana, isto é, a respeito de o que seja uma imagem nas culturas indígenas desta área. Certamente, a imagem parece funcionar como meio de revelação: um desvelamento no sentido de tornar visíveis coisas que normalmente são inacessíveis à vista e ao conhecimento. Olivia Kindl (2005) define as imagens huichol chamadas nierika - desenhos, retratos, estátuas, objetos rituais etc. - como "dispositivos de visão" entre os humanos e os "ancestrais". Uma obra de arte huichol (nierika), observa Neurath (2008:203), manifesta uma dimensão visionária na medida em que dá lugar a outro plano de percepção. O ixiptla nahua - traduzido diversamente como ídolo, representante, figura, imagem, personificação - parece ter o mesmo caráter de manifestação de uma força imanente (López-Austin 1973; Gruzinski 1994). A palavra tzeltal slok'omba ("imagem") designa coisas como os 
retratos, as fotografias, as figuras dos santos das igrejas ou as estátuas dos próceres nacionais mexicanos, mas também as imagens vívidas dos sonhos ou as visões premonitórias na vigília. Sua tradução literal é "o extraído de si mesmo". Em outras palavras, a coisa se desdobra e mostra seu interior, que é o outro lado do si mesmo. Uma autêntica imagem se caracteriza por precipitar ativamente a comunicação com o outro lado. Um amigo indígena exemplificou este fato com a pintura de um jardim no calendário de um restaurante chinês que estava pendurado na parede de sua cabana. A observação atenta da pintura revelava uma realidade oculta, que ele relacionava com o mundo sobrenatural, onde a própria imagem, por meio de uma sucessão de visões, "guiava" a reflexão.

Deparamo-nos, em resumo, com um tipo de imagem subjetivamente ativa, que se apropria do campo de visão do observador. Menos uma representação que uma presença, a imagem é alguém capaz de nos olhar. Uma imagem, por assim dizer, "ergativa" em que o objeto adota a forma ativa e o sujeito se torna passivo. Como diz Viveiros de Castro (2006:325) dos espíritos amazônicos, "imagens ativas, índices que nos interpretam antes que os interpretemos; enigmáticas imagens que devem nos ver para que possamos vê-las". E, decerto, para poder entabular uma relação com um espírito, ou seja, com uma imagem, ele deve nos olhar previamente. A fórmula tzeltal para se dirigir a qualquer espírito auxiliar é precisamente:

me conceda o espelho de teu olhar

me conceda o espelho de teu rosto

Nas línguas maias, cabe dizer, a pupila do olho se denomina "espelho" (nen). Agora, se os espíritos são imagens - slok'omba, "o extraído de si mesmo" - é porque manifestam um esquema invertido com respeito aos seres humanos. Provavelmente o melhor exemplo disto são os santos católicos cujas imagens - de uma perspectiva indígena - correspondem à imagem parcialmente externalizada de um ser humano ordinário (Pitarch 2013). O interior se situa no exterior e vice-versa, tal como acontece com o feto durante a gestação. Daí que os santos exibam abertamente aquilo - animais e objetos próprios de sua representação iconográfica cristã - que entre os seres humanos ordinários se encontra dobrado dentro do coração como almas ou "nahuales". Olhar um santo equivale, então, a se olhar em um espelho que revela o outro lado de si mesmo enquanto espécie.

Finalmente, os espelhos mesoamericanos possuem outra qualidade importante: seu caráter fragmentado. Os espelhos pré-colombianos são frequentemente formados por um mosaico de peças de pirita ou hematita (por exemplo, cf. Healy \& Blainey 2011). Os deuses pré-colombianos maias 
são representados - especialmente quando o são de maneira antropomórfica - constelados de pequenos espelhos por todo o corpo (Rivera 1999). Tal predileção indígena pelos espelhos fragmentados se verifica também entre as personagens sagradas contemporâneas. Santos e virgens (nossas senhoras) da região de Altos de Chiapas, por exemplo, costumam portar no peito - no lugar onde se encontra o coração - uma coleção de pequenos espelhos de diferentes formas e intensidades: quadrados, ovais, com as quinas arredondadas, brilhantes, escuros etc. (cf. fig. 4). Em outras palavras, os espelhos, em lugar de refletirem a imagem do humano à sua frente, fragmentam-na e multiplicam-na - multiplicam para dividir e vice-versa (uma escala fractal, simultaneamente plural e singular $)^{10}$. Longe de mostrar a unidade e a identidade - literalmente o "si mesmo" - característico do mundo solar, a imagem no espelho revela a multiplicidade e a alteridade distintiva do outro lado ou, mais precisamente, de si mesmo refletido pelo outro lado: o "si mesmo como outro/s".

Fig. 4. Virgen de Magdalenas, Altos de Chiapas.

\section{Foto (fragmento) de José Ángel Rodríguez}

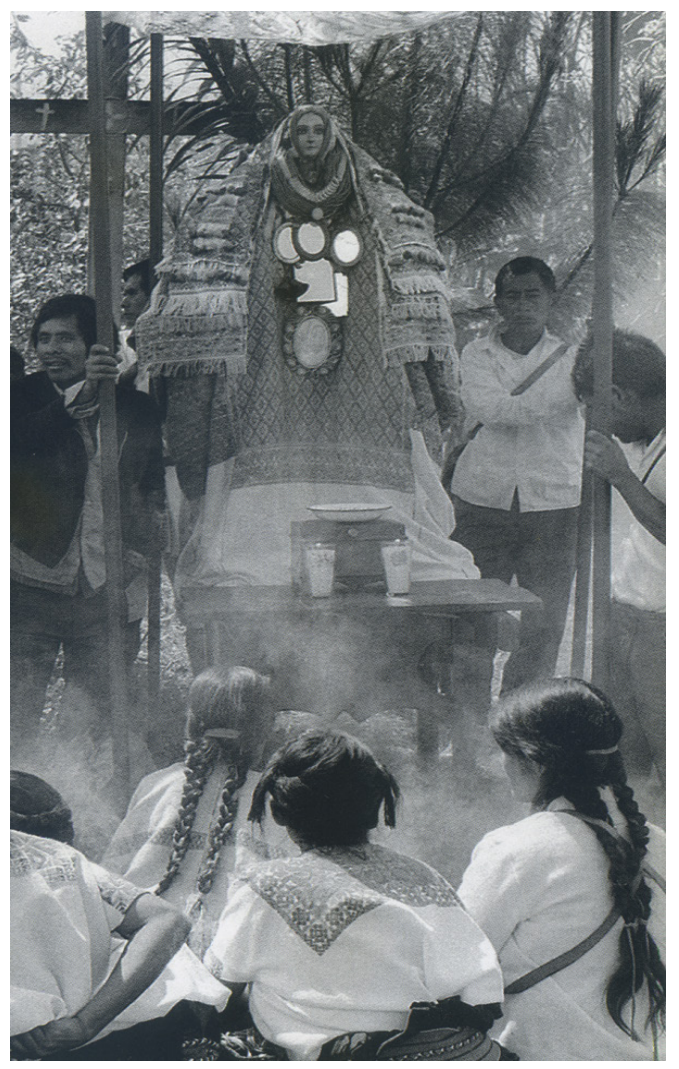




\section{Vice-versa}

A inversão entre a figura e o fundo se projeta em numerosos aspectos do mundo cotidiano indígena, dentre os quais está a distribuição do lugar habitado. Tomemos como exemplo o povoado tzeltal de Cancuc. A praça central - o retângulo onde se encontram a igreja, a prefeitura, a escola e outras dependências públicas, ou seja, aquilo que representa o poder colonial espanhol o nacional mexicano - é denominada "coração do lugar". Como as almas no interior do coração humano, a praça reproduz fragmentos do "fora" necessários para constituir o povoado e, de fato, foi assim que aconteceu historicamente. No século XVI os missionários dominicanos forçaram uma dobra: implantaram a praça (como se implanta um embrião) e por meio desta manobra introduziram o nascimento do povoado. No entanto, o povoado resultante não foi aquilo que tinham previsto os frades, porque os indígenas se negaram a construir ruas e casas e continuaram vivendo dispersos. Em outras palavras, a praça concentra o dado primordial no qual os indígenas carecem propriamente de controle, e o assentamento disperso equivale ao "corpo", cujo desenvolvimento e manutenção são responsabilidade dos seres humanos que o habitam. Um povoado, afinal, nasce dobrando-se sobre si mesmo e arrastando consigo para este mundo um grumo de forças do outro lado - instituições e outros fragmentos do Estado - que permanecem confinadas (idealmente) na praça (Pitarch 2013).

Até o momento presente, a independência política de uma aldeia em relação ao seu município ou o sucesso de uma rebelião eles eram quase sempre precedidos tanto pela edificação de um templo ou ermida como pelo estabelecimento de um novo mercado. É um dado conhecido que a fundação de cidades mesoamericanas pré-colombianas se iniciava com a demarcação de uma praça e a instalação de um templo e um mercado (cf. Oudijk 2002). Pergunto-me se a prática de trazer para o centro da cidade peças naturais ou artificiais procedentes dos confins do mundo - objetos oceânicos, animais estranhos, estilos arquitetônicos estrangeiros etc. - não guarda relação precisamente com o exercício de constituição desta pela via de uma dobra do exterior. Podemos pensar, assim, na prática de depositar na construção das pirâmides oferendas de objetos e animais exóticos - areia marinha, conchas, corais, minerais, penas, ossos, cabelo, presas caninas, instrumentos musicais, relíquias de cidades desaparecidas... (cf. López Lujan 1993) - muitos dos quais remetem, por certo, ao conteúdo dos embrulhos.

Templo e mercado representam, então, o coração do lugar: a zona de captura de recursos espirituais do exterior instalada no lugar mais central do povoado. Ambos são a condição para que a comunidade adquira existência independente, de forma paralela a como, na ontogênese indígena, o coração 
é o primeiro órgão a se formar e a criatura só principia a desenvolver um corpo propriamente independente a partir do nascimento, momento no qual o coração começa a palpitar.

Tudo o que acabamos de ver indica que o mercado - o mercado mesoamericano - pode ser interpretado como uma dobra do outro lado. No mercado, pessoas vindas de distintas aldeias, povoados, vales, com diferentes indumentárias, dialetos ou línguas, entram em contato, e o fazem sob regras que, longe de serem locais, são pensadas como universais. Isto torna o mercado uma pequena condensação do estado virtual: um campo de complicação, tanto entre pessoas como entre produtos heterogêneos, um "entrar em contato" de seres cuja diferença não é "cultural", mas "natural". Ainda mais, no mercado o comportamento social se torna estranho e as normas de etiqueta e interação corporal se transtornam. A necessária distância física entre pessoas que define a vida cotidiana se colapsa. O espaço fica tão saturado que dificilmente há lugar para se mover entre as tendas e pessoas. Os corpos solapam, borrando seus limites e misturando suas diferenças. Todas as conversas se confundem em um característico rumor surdo. Enfim, durante umas poucas horas, neste pequeno mare Magnum, se detém o contínuo e metódico trabalho social de distinguir espécies, povos e línguas entre si (cf. fig. 5).

\section{Fig. 5. Mercado de Cancuc. Foto Pedro Pitarch}

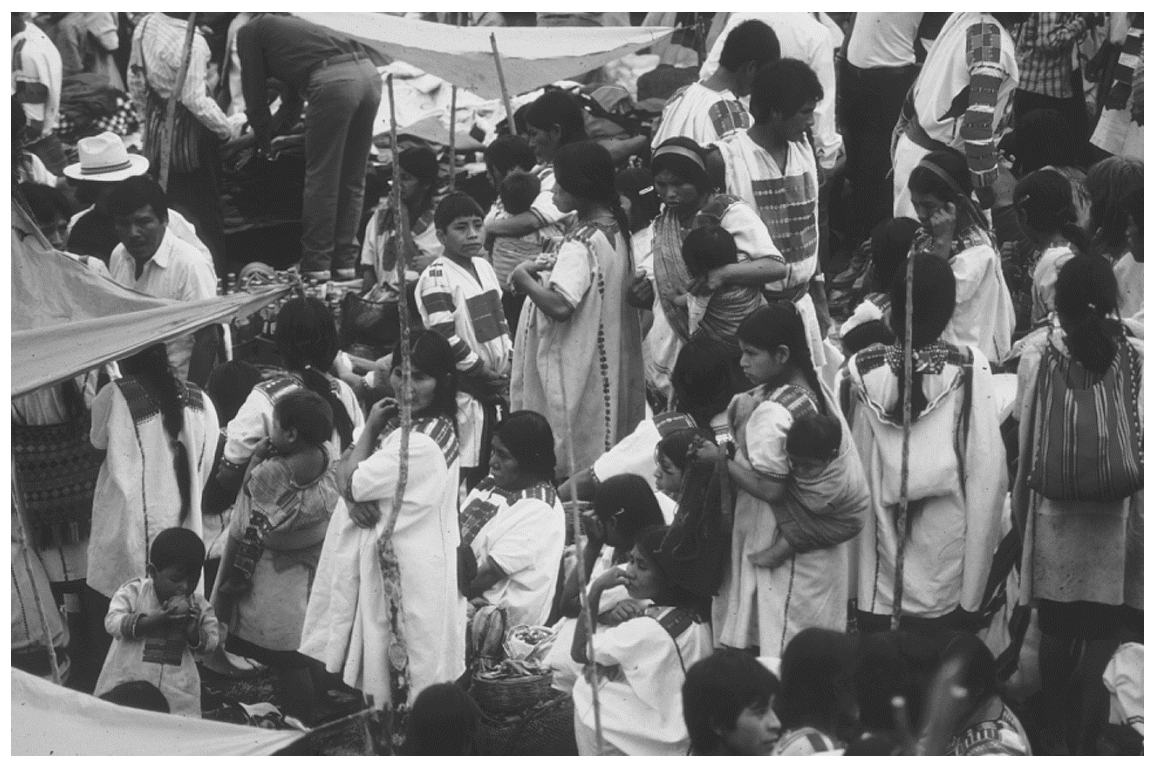

Imagino que deve ter sido esta qualidade que levou Bronislaw Malinowski a qualificar o compulsivo interesse mesoamericano pelo mercado 
como "libido comercial" (Malinowski \& De la Fuente 1957). O principal incentivo do mercado é, sem dúvida, comerciar, porém ninguém que já visitou um mercado indígena pôde deixar de notar o gosto produzido simplesmente por estar lá, naquela condensação humana, sem necessidade de comprar ou vender nada. Seria inexato dizer que é um lugar de diversão. Antes, é um estado de regozijo sombrio - uma pulsão, para dar continuidade à linguagem freudiana utilizada por Malinowski - de se entregar a um modo de relação estranha. Um afeto que submerge transitoriamente os participantes em um estado próximo ao da complicação pré-solar.

Ir da figura bem diferenciada da vida cotidiana ao fundo confuso do mercado implica passar de um mundo discreto de intervalos regulares a um mundo contínuo. Tal inversão equivale, como vimos, à diferença entre o anverso e o reverso de uma peça indígena tecida. A inversão figura/fundo corresponde, em definitivo, à dobra entre o anverso e o reverso de um tecido.

Figura 6. Vaso K621. Archivo Justin Kerr

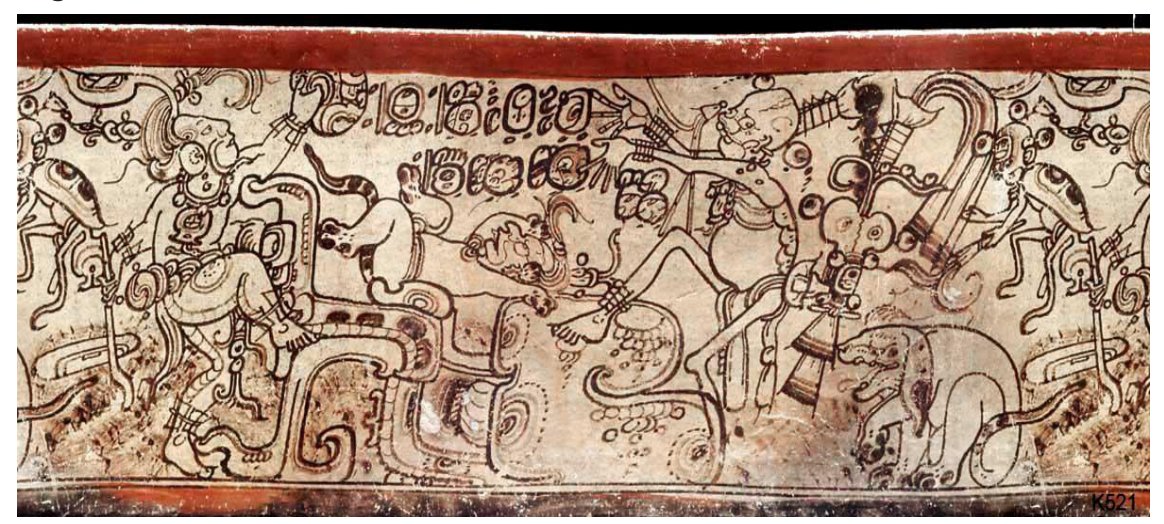

Podemos perceber algo deste contínuo heterogêneo na imagem da figura 6, que corresponde a um vaso clássico maia no qual se representa uma cena "sobrenatural". Provavelmente o que chama a atenção à primeira vista são as estranhas personagens que aparecem na cena; mas, se prestarmos um pouco mais de atenção, é de fato a própria atmosfera que resulta extravagante. Nela se reconhecem alguns aspectos já mencionados a propósito do mercado: saturação do espaço, ausência de distância entre as figuras, solapamento e transições imperceptíveis entre corpos. Mas, principalmente, destaca-se uma ainda mais geral sensação de "flutuação" ou leveza que parece dirigida a ressaltar a instabilidade das personagens e do cenário mesmo. Tais características se acentuam por comparação com a figura 3, vista anteriormente, na qual os corpos se encontram perfeitamente delineados, separados e fixados pelo seu próprio peso. O uso da linha e a cor perseguem uma sensação de 
profundidade e volume nos corpos (Reents-Budet \& Bishop 2012:325), os quais, em contraste com a figura 6 , parecem se desenvolver em um espaço extensivo. Enfim, ambos são vasos maias do mesmo período histórico, mas cada um representa um lado distinto da existência. O dignitário maia da primeira cena poderia estar trazendo, do fundo do espelho, a segunda cena à superfície.

\section{Conclusão}

A operação de dobra distingue e põe em contato simultaneamente o virtual e o atual, a morte e a vida, a alma e o corpo, o sonho e a vigília, o passado mitológico e o presente solar. A dobra de um é o desdobramento do outro: uma dualidade não dualista na qual os dois lados se requerem e intercambiam por meio do tecido reversível do envoltório. Este vertiginoso e transitório jogo da dobra permite articular e fazer coexistirem (não coincidirem) os dois estados opostos do ser sem chegar a produzir verdadeiramente uma mistura ou hibridização. Octavio Paz (1978:38) faz uma magnífica descrição deste funcionamento: "El pliegue esconde entre sus hojas cerradas las dos caras del ser; el pliegue, al descubrir lo que oculta, esconde lo que descubre; el pliegue, al abrir sus dos alas, las cierra; el pliegue es su doblez: su doble, su asesino, su complemento".

Recebido em: 22 de novembro de 2017

Aprovado em: 06 de março de 2018

Pedro Pitarch é professor titular de antropologia na Universidad Complutense de Madrid, Espanha. Email: <petul@ucm.es> 


\section{Notas}

* Muitas das ideias apresentadas neste artigo foram "desdobradas" ao longo de minha estadia como professor visitante no PPGAS do Museu Nacional (UFRJ) durante o ano acadêmico 2014-2015. Quero agradecer vivamente o generoso convite e a hospitalidade de Marcio Goldman e Tania Stolze Lima. Eduardo Viveiros de Castro aceitou amavelmente ser o supervisor de minha bolsa do CNPq e ofereceu valiosas observações ao meu trabalho. Aspectos deste artigo foram apresentados no Museu Nacional e em outras universidades do Brasil e, neste sentido, gostaria de agradecer - e lembrar com saudade - tanto os convites como as observações de, no mínimo: Aparecida Vilaça, Carlos Fausto, Francisco Pazzarelli, Geraldo Andrello, José Antonio Kelly, Luisa Elvira Belaunde, Marcela Coelho de Souza, Marcio Ferreira da Silva, María Elvira Díaz Benítez, María Virginia Ramos Amaral, Oscar Calavia e Renato Stutzman, assim como a ajuda da bibliotecária Dulce Maranha Paes de Carvalho. A tradução é de Ana María Ramo y Affonso.

1 Compare-se com Gow (1997:43) sobre os Piro: “Na condição intra-uterina, o feto não possui interior ou exterior: ele está embrulhado em sua placenta, isto é, em suas próprias entranhas. Depois do nascimento, o bebê se vê separado da placenta, processo que lhe dá um interior e um exterior".

2 Se a pessoa melanésia é um "microcosmo social" (Strathern 1988:275), poderíamos dizer que a pessoa mesoamericana é uma "microsociedade cósmica".

3 Isto me faz pensar que a distinção clássica entre Terras Altas e Terras Baixas americanas poderia ser reformulada como terras de tecido e terras de... pele?

4 Cf. Corsín-Jiménez (2011) sobre as ilusões óticas en trompe-l'oeil da pintura barroca e sua implicação para a antropologia.

5 "Partilhada em refeições coletivas, a carne, sob a forma de alma parcial (dente, pelo, fragmento de osso), poderá acarretar infelicidades para o caçador" (Lima 1996:38).

6 Como se sabe, a etimologia de "múltiplo" é multus (muito) e plus (dobrado). "O múltiplo não é só o que possui muitas partes, mas o que está dobrado de muitas formas" (Deleuze 1991:11).

7 Compare-se com a prática yanomami de projetar a transformação histórica em uma rede geográfica, analisada por José Kelly (2005:213).

8 "When you look into a pool of water or a mirror, the one you see there is not you and it is not human".

9 "The One you see in the mirror who steals your act of looking, but only to see itself."

10 Viveiros de Castro (2013:21) sobre o dualismo diamétrico: "Isso faz com que a relação entre as metades não seja um acréscimo (do tipo $1 / 2+1 / 2=1$ ), mas uma multiplicação, uma repetição de si pelo outro, transformando cada metade em uma função do outra". 


\section{Referências bibliográficas}

BARRERA Vásquez, Alfredo. 1948. El libro de los libros del Chilam Balam. Cidade do México: FCE. . et al. 1980. Diccionario Maya Cordemex. Cidade do México: Cordemex.

CASTAÑEDA, Maria de la Paz. 2016. "La nobleza del centro de México ante la amenaza de sus bultos sagrados". In: P. Lesbre \& K. Mikulska (comps.), Identidad en palabras. Nobleza indígena novohispana. Cidade do México: Unam. pp. 46-86.

CHAMOUX, Marie-Noëlle. 1989. "La notion nahua d'individu: un aspect du tonalli dans la région de Huauchinango (Puebla, Mexique)". In: D. Michelet (coord.), Enquêtes sur l'Amerique Moyenne. Mélanges offerts à Guy Stresser-Péan. Cidade do México: INAH / Conaculta/ Cemca. pp. 95-127.

CLENDINNEN, Inga. 1991. Aztecs: an interpretation. Cambridge: Cambridge University Press

CORSÍN-JIMENEZ, Alberto. 2011. “Daribi kinship at perpendicular angles: a trompe l'oeil anthropology". HAU. Journal of Ethnographic Theory, 1(1):157-177.

COTO, Fray Thomas de. 1983. Thesaurus verboru[m]: vocabulario de la lengua cakchiquel u [el] guatemalteca. Edición de René Acuña. Cidade do México: Unam.

EDMONSON, Munro S. (ed.). 1982. The ancient future of the Itza: the book of Chilam Balam of Tizimin. Austin: University of Texas Press.

DE LA GARZA, Mercedes. 2012. Sueño y éxtasis. Visión chamánica de los nahuas y de los mayas. Cidade do México: Unam/FCE.

DELEUZE, Gilles. 1991. A dobra. Leibniz e o barroco. Campinas: Papirus.

DESVAUX, Emmanuelle. 1988. "Le placenta ou le doublé mort du nouveau-né". Journal de la Societé des Americanistes, 84(1):211-217.

GALINIER, Jacques. 1990. La mitad del mundo. Cuerpo y cosmos en los rituales otomíes. Cidade do México: Unam.

. 2000. "Penser hors de soi: miroirs identitaires en Mésoamérique". Recherches Amérindiennes au Québec, 30(1):9-17.

GARCÍA SOUZA, Paola. 2017. Las rutas del cuerpo. Perspectivas huaves de la corporalidad. Tese de doutorado em preparação, Unam.

GOSSEN, Gary H. 1974. Chamulas in the world of the Sun. Time and space in a Maya oral tradition. Prospect Heights: Waveland Press.

GOW, Peter, 1997. "O parentesco como consciência humana: o caso dos piro". Mana. Estudos de Antropologia Social, 3 (2): 39-65

GRUZINSKI, Serge. 1994. La guerra de las imágenes. De Cristóbal Colón a Blade Runner (1492-2019). Cidade do México: FCE.

HEALY, Paul \& BLAINEY, Mark. 2011 "Ancient Maya mosaic mirrors: function, symbolism, and meaning". Ancient Mesoamerica, 22:229-244.

HERNANDEZ CASTILLLO, Rosalva. 1989. "Del Tzolkin a la Atalaya: los cambios en la religiosidad en una comunidad chuj-kanjobal de Chiapas". In: L. Durán (ed.), Religión y sociedad en el sureste de México. México: CIESAS. pp. 123-224.

INGOLD, Tim. 1991. The perception of the environment. Essays in livelihood, dwelling and skill. Londres: Routledge.

KELLY, José Antonio. 2005. "Notas para uma teoria do 'virar branco'". Mana. Estudos de Antropologia Social, 
11(1):201-234.

KINDL, Olivia. 2005. "L'art du nierika chez les Huichol du Mexique. Un instrument pourvoir". In: C. Michelle et al. (eds.), Les cultures à luvre. Rencontres en art. Paris: Biro / Éditions de la Maison des Sciences del Homme. pp. 225-248.

KLEIN, Cecilia F. 1982. "Woven heaven, tangled earth: a weaver's paradigm of the Mesoamerican cosmos". Annals of the New York Academy of Sciences, 385:1-35.

LIMA, Tânia Stolze. 1996. "O dois e seu múltiplo: reflexões sobre o perspectivismo em uma cosmologia tupi". Mana. Estudos de Antropologia Social, 2(2):21-47.

LÓPEZ AUSTIN, Alfredo. 1973. Hombre-dios. Religión y política en el mundo náhuatl. Cidade do México: Unam.

LÓPEZ LUJAN, Leonardo. 1993. Las ofrendas del Templo Mayor de Tenochtitlan. Cidade do México: INAH.

MALINOWSKI, Bronislaw \& DE LA FUENTE, Julio. 1957. "La economía de un sistema de mercados en México". Acta Anthropologica, 2(1):1-88.

MASON, Peter. 1990. Deconstructing America. Londres: Routledge.

MEGGED, Amos. 2010. Social memory in ancient and colonial Mesoamerica. Cambridge: Cambridge University Press.

MOLINER, María. 1975. Diccionario de uso del español. Madrid: Gredos.

NEURATH, Johannes. 2008. "Alteridad constituyente y relaciones de tránsito en el ritual huichol: iniciación, anti-iniciación y alianza". Cuicuilco, 15(42):29-45.

. 2013. La vida de las imágenes. Arte huichol. México: Artes de México.

OLIVIER, Guilhem. 2007. "Sacred bundles, arrows and new fire: foundation and power in the mapa de Cuauhtinchan $\mathrm{n}^{\circ} 2^{\prime \prime}$. In: D. Carrasco
\& S. Sessions (eds.), Cave, city and eagles nest. An interpretive journey through the Mapa de Cuauhtinchan $N^{\circ}$ 2. Alburqurque: University of New Mexico Press. pp. 123-154.

OUDIJK, Michel R. 2002. "La toma de posesión: un tema mesoamericano para la legitimación del poder". Relaciones, 23(91):96-131

PAZ, Octavio, 1978. Xavier Villaurrutia en persona y obra. Cidade do México: FCE.

PITARCH, Pedro. 1996. Ch'ulel. Una etnografía de las almas tzeltales. Cidade do México: FCE. . 2010. The jaguar and the priest. An ethnography of Tzeltal Souls. Austin: University of Texas Press. . 2012. "The two Maya bodies: an elementary model of Tzeltal personhood". Ethnos. Journal of Anthropology, 77(1):93-115. . 2013. La cara oculta del pliegue. Antropología indígena. Cidade do México: Artes de México.

PITROU, Perig. 2017. "Life form and form of life within an agentive configuration: a birth ritual among the Mixe of Oaxaca, Mexico". Current Anthropology, 58(3):360-380.

POPOL-VUH. 1947. Adrián Recinos (ed.). Cidade do México: FCE.

QUESTA, Alessandro. 2018. "Visible dancers and invisible hunters. Divination and masking among the Nawa in the mountains of eastern Mexico". P. Pitarch \& J. Kelly (eds.), The culture of invention in the Americas. Anthropological experiments with Roy Wagner. Londres: Kingston. pp. 98-123.

REENTS-BUDET, Dorie \& BISHOP, Ronald L. 2012. "Classic Maya painted ceramics: artisans, workshops, and distribution". In: J. Pillsbury et al. (eds.), Ancient Maya art at Dumbarton Oaks. Washington: Dumbarton 
Oaks. pp. 64-96.

REICHARD, Gladys A. 1972 [1932]. Spider woman: a story of Navajo weavers and chanters. Alburquerque: University of New Mexico Press.

RIVERA, Miguel. 1999. “Espejos mágicos en la cerámica maya". Revista Española de Antropología Americana, 29(2):65-100.

STRATHERN, Marilyn. 1988. The Gender of the Gift: Problems with Women and Problems with Society in Melanesia. Berkeley: University of California Press.

STUART, David. 1996. "Kings of stone: a consideration of stelae in ancient Maya ritual and representation". Res: Anthropology and Aesthetics, 29-30(2):148-171.

TEDLOCK, Barbara. 1982. Time and the highland Maya. Alburquerque: University of New Mexico Press.

TEDLOCK, Dennis. 2010. 2000 years of Mayan literature. Berkeley: University of California Press.

VILAÇA, Aparecida. 2005. "Chronically unstable bodies: reflections on Amazonian corporalities". Journal of the Royal Anthropological Institute, (N.S.) 11:445-464.

VIVEIROS DE CASTRO, Eduardo. 2002a. "Perspectivismo e naturalismo na América indígena". In: A inconstância da alma selvagem - e outros ensaios de antropologia. São Paulo:
Cosac \& Naify. pp. 345-400.

. 2002b. "Actualização e contra-efectuação do virtual: o processo do parentesco". In: A inconstância da alma selvagem - e outros ensaios de antropologia. São Paulo: Cosac \& Naify. pp. 401-457. . 2006. "A floresta de cristal: notas sobre a ontologia dos espíritos amazônicos". Cadernos de Campo, 14/15:319-335

. 2013. "Radical dualism: a meta fantasy on the square root of dual organizations, or a savage homage to Lévi-Strauss". In: 100 Notes - 100 thoughts / 100 notizen - 100 Gedanken. Documenta Series, 56:1-43

WAGNER, Roy, 1981. The invention of culture. Chicago: Chicago University Press.

. 2001. An anthropology of the subject. Berkeley: University of California Press.

. 2010. "Foreword". In: P. Pitarch, The jaguar and the priest. An ethnography of Tzeltal souls. Austin: University of Texas Press.

. 2013. "Keeping the secret of culture from itself: the science of perspectivism". Manuscrito.

WEITLANER, Irmgard. 1967. "Textiles". In: D. Byers (ed.), The prehistory of the Tehuacan Valley. Austin: University of Texas Press. pp. 174-195. 


\section{A LINHA DA DOBRA. ENSAIO DE COSMOLOGIA MESOAMERICANA}

\section{Resumo}

O ensaio propõe a figura da dobra como um conceito crucial para entender a cosmologia da área indígena mesoamericana. A dobra é o modo de relação entre os dois lados ou estados do cosmos: o estado solar habitado pelos humanos e o estado virtual dos espíritos. A figura da dobra remete ao tecido, o qual representa um modelo básico de invenção e transformação nas culturas mesoamericanas desde os primórdios da arte têxtil, há cerca de 3.000 anos atrás, até o presente. A alternância entre um e outro lado do cosmos equivale à diferença entre o anverso (nítido, descontínuo) e o reverso (turvado, contínuo) de uma peça indígena tecida. $\mathrm{O}$ artigo examina certos temas clássicos da antropologia mesoamericana à luz desta operação de dobradura: o nascimento individual, as manipulações sobre o tecido, as dobras do corpo, os vultos ou envoltórios sagrados, a natureza do tempo, a imagem e o espelho, o mercado.

Palavras-chave: Mesoamerica, Cosmologia, Dobra, Tecido, Envoltórios sagrados, Espelhos.

\section{THE FOLD LINE. AN ESSAY IN MESOAMERICAN COSMOLOGY}

\begin{abstract}
This article proposes the figure of the fold as a crucial concept to understand the cosmology of the Mesoamerican indigenous area. The fold is the mode of relationship between the two sides or states of the cosmos: the solar state inhabited by humans and the virtual state of the spirits. The figure of the fold refers to the textile fabric, which represents a basic model of invention and transformation in Mesoamerican cultures, from the beginnings of textile art some 3000 years ago to present time. The alternation between one side and another of the cosmos equals the difference between the obverse (clear, discontinuous) and the reverse (blurred, continuous) of an indigenous woven piece. The article examines certain classic themes of Mesoamerican anthropology in the light of this folding operation: the individual birth, the manipulations on the fabric, the folds of the body, the sacred bundles or wrappings, the shape of time, the image and the mirror, the nature of the market. Key words: Mesoamerica, cosmology, fold, textile, sacred bundles, mirror.
\end{abstract}




\section{LA LÍNEA DE PLIEGUE. ENSAYO DE COSMOLOGÍA MESOAMERICANA}

\section{Resumen}

Este artículo propone la figura del pliegue como un concepto crucial para entender la cosmología del área indígena mesoamericana. El pliegue es el modo de relación entre los dos lados o estados del cosmos: el estado solar que habitan los humanos y el estado virtual de los espíritus. La figura del pliegue remite al tejido, el cual representa un modelo básico de invención y transformación en las culturas mesoamericanas, desde los inicios del arte textil hace unos 3000 años hasta el presente etnográfico. La alternancia entre un lado y otro del cosmos equivale a la diferencia entre el anverso (nítido, discontinuo) y el reverso (difuminado, continuo) de una pieza tejida indígena. El artículo examina ciertos temas clásicos de la antropología mesoamericana a la luz de esta operación de pliegue: el nacimiento individual, las manipulaciones sobre el tejido, los pliegues del cuerpo, los bultos o envoltorios sagrados, la forma del tiempo, la imagen y el espejo, la naturaleza del mercado.

Palabras clave: Mesoamérica, Cosmología, Pliegue, Tejido, Envoltorios sagrados, Espejos. 